Article

\title{
The Role of Culture in the Self-Organisation of Coastal Fishers Sustaining Coastal Landscapes: A Case Study in Estonia
}

\author{
Anu Printsmann * and Tarmo Pikner \\ Centre for Landscape and Culture, School of Humanities, Tallinn University, Uus-Sadama 5, \\ 10120 Tallinn, Estonia \\ * Correspondence: anu.printsmann@tlu.ee
}

Received: 11 March 2019; Accepted: 17 July 2019; Published: 20 July 2019

check for updates

\begin{abstract}
The cultural sustainability of coastal landscapes relies heavily on the community's self-organisation in fish foodways. The theoretical framework concentrates on cultural sustainability, foodways, land-sea interactions, and community of practice. The data presented in this article were part of the SustainBaltic Integrated Coastal Zone Management plan, consisting mainly of semi-structured and focus group interviews with stakeholders, supported by background information from various available sources. The results are outlined by descriptions of self-organisation, community matters, and food forming cultural sustainability of coastal landscapes. The self-organisation in community of practice among coastal fishers is slowly progressing by negotiating common resources and voicing concerns about ecological, economic, and social sustainability. Foodways, which comprise the indispensable ingredient for sustaining a way of life that has produced traditional coastal landscapes, are always evolving.
\end{abstract}

Keywords: fishing; cultural sustainability; community of practice; landscape; Estonia

\section{Introduction}

In recent food fads, a lot of attention has been paid not only to edible things themselves, but everything involved in and around them [1]; for example, seeds and soil, fertilisers and pesticides, animals and plants, wild, free-range and industrially grown, the length of supply chains, marketing, labelling, and so on [2,3]. The reason behind this is that the majority of urbanites have lost their connection with their food-where it comes from, what it needs to grow, how it changes the immediate surroundings and wider environment-making all kinds of self-organised individual and collective food growing activities more popular than ever. These tendencies indicate a "re-spatialising" and "re-socialising" of food, which has drawn attention to alternative or short food networks and problematised the "local" in relation to wider interdependencies [4,5]. Food brings together the natural, economic, social, and cultural realms of life with transformative power over the planet as even hunting and gathering practices have altered the landscapes. In the context of current interests in food, its origins, and influence, this article explores the evolving culture of self-organisation of coastal fishers in Estonia. The paper argues that the fish foodways are paramount in sustaining coastal landscapes.

Foodways are the cultural, historical, social, and economic practices relating to the production and consumption of food. Coastal fishing is one of the oldest foodways persisting to this day. Ancient temporary fishing sites are sometimes still recognisable in landscapes. Such a basic activity as food provision is resilient to every socio-political circumstance as long as the environment is capable of providing these affordances. Age-old yet ever-changing fishing equipment, boats, paths to mooring locations, fish preparation sites, and distribution ways form a part of human condition on the coast. 
The Lääne-Viru coastal area in Estonia explored in this article was one of the study sites included in the SustainBaltic project focused on the Integrated Coastal Zone Management (ICZM) Plans for Sustaining Coastal and Marine Human-ecological Networks in the Baltic Region [6,7]. The area struggles to keep permanent inhabitants despite being a renowned summer resort. Geographical marginalisation and outmigration threaten to disconnect the cultural heritage of fishing from the contemporary economy. Yet traditional foodways have comprised an indispensable ingredient in sustaining a way of life that has produced traditional cultural landscapes that could be used in recreational activities enhancing local development. Local communities and especially the fishers need to come up with auxiliary activities for fishing to maintain the coastal landscapes attracting domestic and foreign tourists. One of the incentives for writing up this paper was the lack of local fish on the menus of restaurants in the Lahemaa National Park despite that traditional, local, or regional, seasonal, slow food have been otherwise become much appreciated by foodies [8].

We will show how the constant adaptation of the self-organisation of coastal fishers in foodways contributes to the cultural sustainability of landscapes. The particular focus is on cultural aspects of sustainability, land-sea interactions, and self-organisation through the community of practice concept. The case study about the Lääne-Viru coastal area provides contextual knowledge about wider tendencies affecting the revival of coastal fisheries and related landscapes in Estonia and beyond.

\section{Theoretical Framework}

We argue that cultural sustainability is the key to understanding how the self-organisation of coastal fishers sustains foodways and consequently landscapes.

\subsection{Three Ways to Combine Culture and Sustainability}

The increasing pressure on fragile and rich coastal ecosystems has resulted in a call for holistic sustainability transitions, which could upscale and distribute sustainability lessons and take into account spatial differences [9]. These transitional approaches could benefit from cultural aspects of sustainability. Sustainability has traditionally been seen as consisting of three pillars: Ecological, economic, and social.

Sometimes separating the social and cultural dimensions of life can be difficult but it is very often that moral codes direct our behaviour to help us finalise social norms about what is acceptable and what is not. These rules of conduct not only vary from one continent to the next, but also from one community and neighbourhood to another, determining what makes an acceptable way of life. This is how culture shapes the landscape [10]. These systems have evolved and become more or less adapted to the environment. Diverse values and skills are part of a coastal fisher's ability to adapt to changing circumstances through the manipulation of a self-reliant small commodity production mode of life and through establishing new forms of multifunctionality [11]. Radical changes may disturb the fragile balance as each system has developed its own coping mechanisms and methods. This is why there are no universal solutions in society [12-14].

In the 21st century, an effort to factor in culture has been made $[15,16]$ with projects [13] dedicated to understanding how to connect culture and sustainability (Figure 1):

1. Culture in sustainability (Figure 1a) looks at culture as an independent dimension for sustainability alongside ecological, economic, and social pillars. Culture is treated as a capital in its own right: As an achievement in development or where material and intangible heritage needs to be conserved, preserved, and maintained for the future generations

2. Culture for sustainability (Figure 1b) refers to culture as a more influential force that can operate beyond itself having a mediating role to achieve the overall aims of sustainability. Culture is integrated within the ways in which we behave in green environments, what kind of decisions we make in the business world, and according to which principles we organise our social sphere. Culture as a way of life forms a basis for advancement of life in all dimensions 
3. Culture as sustainability (Figure 1c) considers culture as a foundation for sustainability. It handles development as a cultural process by recognising that culture is at the root of all human decisions and actions and an overarching concern (even a new paradigm) in sustainable development thinking. Culture and sustainability become mutually intertwined, and the distinctions between the economic, social, and environmental dimensions of sustainability begin to fade [13] (pp. 28-29).
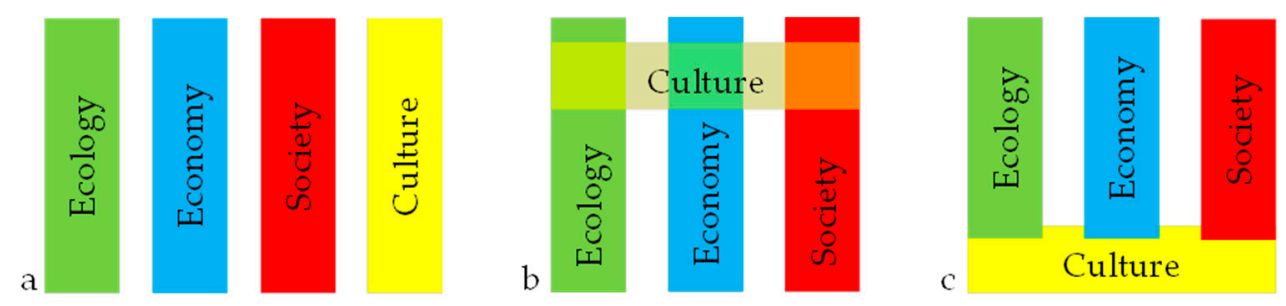

Figure 1. Cultural aspects of sustainability: Culture as (a) a fourth pillar (culture as a capital), (b) a mediator, and (c) an underlying condition, based on $[13,17]$.

We will show how these different cultural aspects of sustainability affect the self-organisation of coastal fishers in enacting foodways contributing to the sustainability of coastal landscapes.

\subsection{Foodways: From Landscape to Sea}

Foodways encompass the whole interrelated system of food conceptualisation and evaluation, procurement, preservation, preparation, consumption, and nutrition shared by all members of a particular society [18]. All these activities leave a spatial pattern or landscape, having natural, economic, and socio-cultural counterparts. Landscape is "a social space denoting territory and its people with connected aspects of custom, value, and everyday life" [19] (p. 139), [20,21]. Making things in a certain way, inevitably and unconsciously adhering to a way of life results in particular arrangements of things on the land [22] (p. 49); for example, the placement of landing sites and net sheds among fisher folk. Very seldom does somebody intentionally set out to create a landscape: Usually it is a side-product of everyday life and also foodways, which, with their inner logic, become valuable $[23,24]$ as a unique constellation in a specific time-space. Here is the scene for culture as a fourth pillar and capital [17] where heritage in a traditional sense can be protected. Alternative (or short with few intermediaries) food networks, based on interpersonal relations of trust, are economic exchanges around which food become "culturalised" in the sense that they rely on the conventions and values surrounding the food produced [4]. This means that beside social embeddedness, food can valorise cultural and political (e.g., food security) aspects that generate connections between people and their wider surrounding environments, whereas culture becomes means of mediating [17] these relations in sustainability process. For understanding foodways we need to know more about local cultures and landscapes.

There is a challenge to scrutinise the landward bias in understanding landscapes [25]. Very often meaningful social spaces of human habitation are associated with shaped land territories. However, coastal areas vividly valorise that certain values and everyday practices exceed the land terrain involving seas and generating land-sea interactions. So as much we can speak of cityscapes, we can also use seascapes, although physical patterns may not always be discernible, mental ones co-exist with practices. Certain situated rules of conduct apply to the sea as in the forest or the townscape. Following customs and values entangled in fishing can reveal embedded relations between foodways and the sea/landscape. Here, some disturbed relations become important in understanding the cultural sustainability of coastal landscapes. Landscape can be a product of tensions between tangible presence(s) and what is absent within the experienced surroundings [26,27], like the local fish from the menus of restaurants in coastal villages although boats and fish nets are visible. Fish foodways shape coastal landscapes with cultural practices and tangible alterations. 


\subsection{Community of Practice in Self-Organisation}

A community of practice $(\mathrm{CoP})$ is defined as "a system of relationships between people, activities, and the world; developing with time, and in relation to other tangential and overlapping communities of practice" [28] (p. 98). This means that the practices of coastal fishers form a cultural way of life binding them socially and economically, and simultaneously connecting them to the surrounding world and generating interpretations about coastal landscapes. $\mathrm{CoP}$ as a cultural practice mediates the ecological, economic, and social dimensions of sustainability. Self-organisation is part of CoP, valorising diverse capacities to form and realise individual and/or collective initiatives, applying gathered cultural knowledge as capital. There is potential to elaborate the aspects of CoP through a closer analysis of processes of self-organisation. According to Kaufmann [29] (p. 60), "self-organisation is thus understood as the contrary of two stakes: lack of organisation and organisation forced by external forces", which raise issues of autonomy from outside resources and self-maintenance. For example, autonomy- and empathy-based processes appear as a core part of the identity of Scottish coastal fishermen, which is reinforced by external challenges that serve to threaten flexible fishing strategies [30]. It means that self-organisation refers to some forms of autonomy, which mobilise particular ways of bringing culture together with coastal landscapes. Here, it is important to recognise the dynamics connecting the external pressures on communities and the personal motivations of fishing practice contributing to wider sustainable coastal landscapes. CoP methodologies reveal that different (professional and vernacular) activities establish diverse social and cultural affinities between actors and their environs [31]. For example, we would expect IT-designers working on a new product to engage in different activities compared to fishers preparing and working towards a good catch. However, certain CoPs co-exist with other social ties and groups, which distribute things, knowledge, and resources among other elements. Coastal fishers also have to buy and repair equipment, report their catch, and sell fish. Therefore, the foodways became enacted and co-produced with diverse CoPs including relations to coastal landscapes. The self-organisation of fishing activities depends on accessibility to, and governance of, marine areas, where the increasing concern for recreational and environmental protection can also generate negative public attitudes towards fishing as a profession [11].

The formation of knowledge and situated learning in practical activities is central in the formation of communities [32]. The tacit aspects of knowledge require presence and social proximities in learning by doing, which (ecologically) situates activities also within coastal landscapes. Fisher folk often carry their knowledge, habits, and place-based skills/stories across generations without clear explicit handbooks; for example, the mending of fish nets can be seen as a part of intangible cultural heritage. This indicates traditional ecological knowledge, which co-exists with environmentally embedded activities and skills forming coastal landscapes in particular ways [33]. For example, the maintenance of foodways leaves tangible things on the shore considered as part of the cultural landscape. These things in landscapes could easily disappear or become empty markers without vivid CoP and related ecological knowledge. This means that the ecological knowledge of CoPs can play an important role in the care and persistence of coastal landscapes.

\section{Case Study}

Our case study site is primarily situated in Haljala municipality in Lääne-Viru county, Estonia, on the southern rim of the Finnish Gulf in the Baltic Sea. Coastal landscapes being liminal phenomena might come across as ecotones featuring the best of mainland and aquatic natural resources, making them versatile and resilient subsistence systems through the ages. Yet, the coastal areas in northern Estonia counterpoint that premise, as the shallow soils are rather barren and catches from the Baltic Sea inconsistent.

Nevertheless, coastal communities in Estonia that use fishing activities to survive have traditionally excelled in self-organisation to secure foodways with the help of multitasking like smuggling contraband of highly taxed goods like salt and fuel or liquor under dry laws to and from Finland. "Friend barter" 
practices have been established since times immemorial. The fishing catch was also traded inland across Estonia for potatoes and other merchandise.

With the rise in living standards, alternative and supplementary endeavours developed. Boat and ship building boomed hand-in-hand with educational opportunities. By the beginning of the 20th century, income from holiday-makers had also grown substantially. "Summer-rooms" were let for the upper classes of the Russian Empire, mainly from St. Petersburg and also the Estonian intellectuals and arts set (Figure 2). However, this boom of maritime culture became part of "ruptured landscapes" [34] under Soviet rule (1940-1941 and 1944-1991) when many of the freedoms that are a normal part of a democratic society were abolished. There was no right to organise bottom-up (political) gatherings, although this policy was relaxed in the later years of the Soviet regime. Private enterprise was forbidden and fisheries were controlled via state-owned collective farms on an industrial scale. Individual fishing was banned, and small boats were destroyed to prevent people fleeing to Finland or Sweden. The "iron curtain" sealed off all sea-connections with Western countries. Although the ferry line between the capital cities of Estonia (Tallinn) and Finland (Helsinki) was re-opened in 1965, access to the coastline was still regulated by formal permits. The restricted border zone preserved the largely undeveloped nature of the coastline [35,36]. Alongside Soviet resorts, the rental of private rooms survived as part of the barter-based shadow economy [37]. After Estonia regained its independence in 1991, traditional foodways were partly restored, although the maritime culture as a way of life has not been revived to its former glory [38]. For example, in Sweden, the number of adults per pleasure boat is around eight, thus making it one of the top countries in the world alongside Finland, Norway, and New Zealand [39]. In Estonia, there are 40 people per water vehicle [40,41]—there is a long way to catch Sweden.

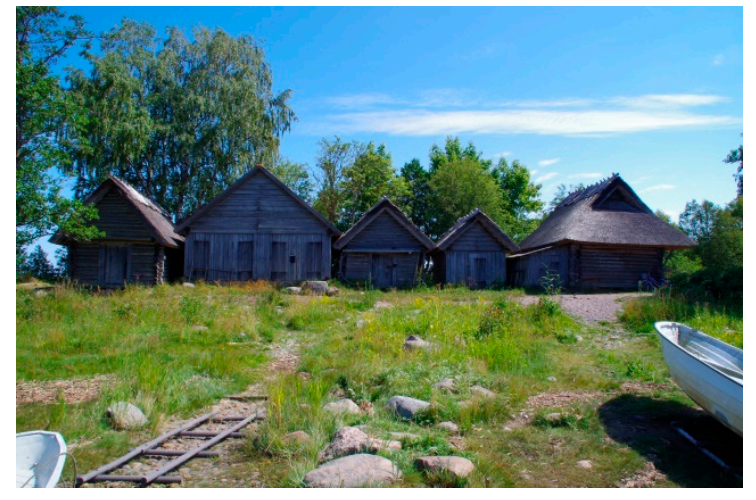

(a)

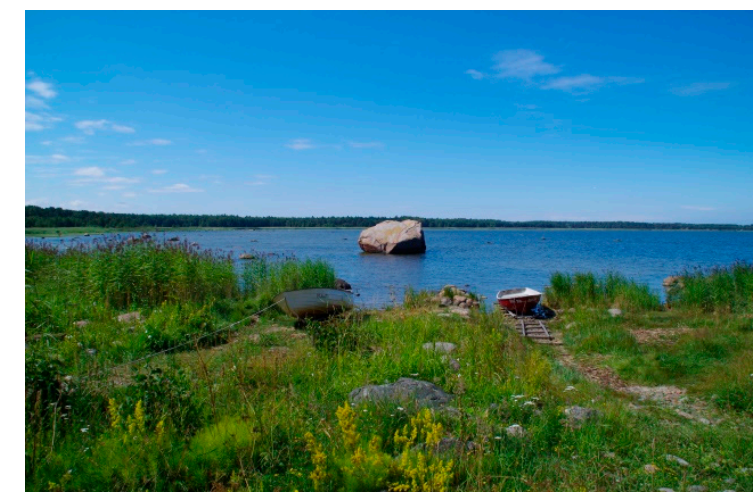

(b)

Figure 2. The view (a) of and (b) from the iconic (albeit dilapidated) net sheds at Altja in Lahemaa National Park, Estonia. The net shed on the right served as a handicraft kiosk during the summer of 2018. Similar boat sheds are sometimes transformed into summer cottages or their appearance is copied (photograph: Anu Printsmann, 11 July 2018).

Fishing had previously been an economic mainstay and now it endures the confluence of path dependency of half a century missing practice and contemporary bureaucracy. The historical disposition is a result of the slow transition of the post-communist situation, where not all state collective enterprises were successfully privatised. The privatisation process redistributed the infrastructure and coastal premises of the former industrial fishery and contributed to emergent forms of entrepreneurship related to small-scale fishing. Some similar tendencies appear along the Terskii Coast (in Russia), where the post-socialist setting allows much less regulated access to fish resources, triggering commodification tendencies and revealing different values between locals and incomers towards commercial fishing [42]. The practices of coastal fishers intercede with governance bodies even to the level of European Union (EU) regulations and support schemes; however, a fair share of their production is being sold from hand-to-hand to the local community. In a way, this very short supply chain is much sought after 
in the contemporary world, although it is in place as a contingency because the other options are less favourable.

Tensions in the community of practice among coastal fishers arise from using shared resources, such as the sea, fishing rights and permissions, common law, local agreements, catch areas, and mooring sites. In Estonia, as in many Nordic countries, everyone has the right and freedom to roam, in addition to coastal pathways a no-building restriction zone exists on the coast. Similar tensions based on shared resources are indicated in the sea around the Finnish Archipelago, where fishers also have to negotiate with groups of second-home owners who also have the right collectively to decide on fishing permits [11]. On the other hand, they are united in their concern for the sustainable management of fish stock, as their livelihood depends on it, and the sustainability of their profession is threatened by the lack of progeny and ancillary income activities, since fishing is not profitable [43]. Therefore, the case study illustrates wider post-productionist transitions of coastal landscapes, which generate a shift from an emphasis on food production to a diversity of new activities, including recreation, tourism, and nature conservation [11]. In the European context of Blue Growth, however, the environment may be the weakest component, as there are concerns about how healthy the fish from the Baltic Sea are for eating. Blue Growth is the long-term strategy to support inclusive and innovative growth in the marine and maritime sectors as a whole [44]. The sea could be used much more for economic development if it is done in a smart and sustainable way.

\section{Methodological Background}

\subsection{Project on Integrated Coastal Zone Management}

The data collected to tease out the link between fishing and the cultural sustainability of coastal landscapes originate from SustainBaltic, a project financed by the European Regional Development Fund through the Interreg Central Baltic programme. The title of the project was ICZM Plans for Sustaining Coastal and Marine Human-ecological Networks in the Baltic Region [6]. The project, involving five partners from Estonia and Finland, lasted from 1 September 2016 until 30 November 2018 with one of the study areas situated in Haljala municipality in Lääne-Viru county, Estonia.

ICZMs are bound by a broad holistic and participatory [45-49] landscape planning approach $[50,51]$ (Figure 3).

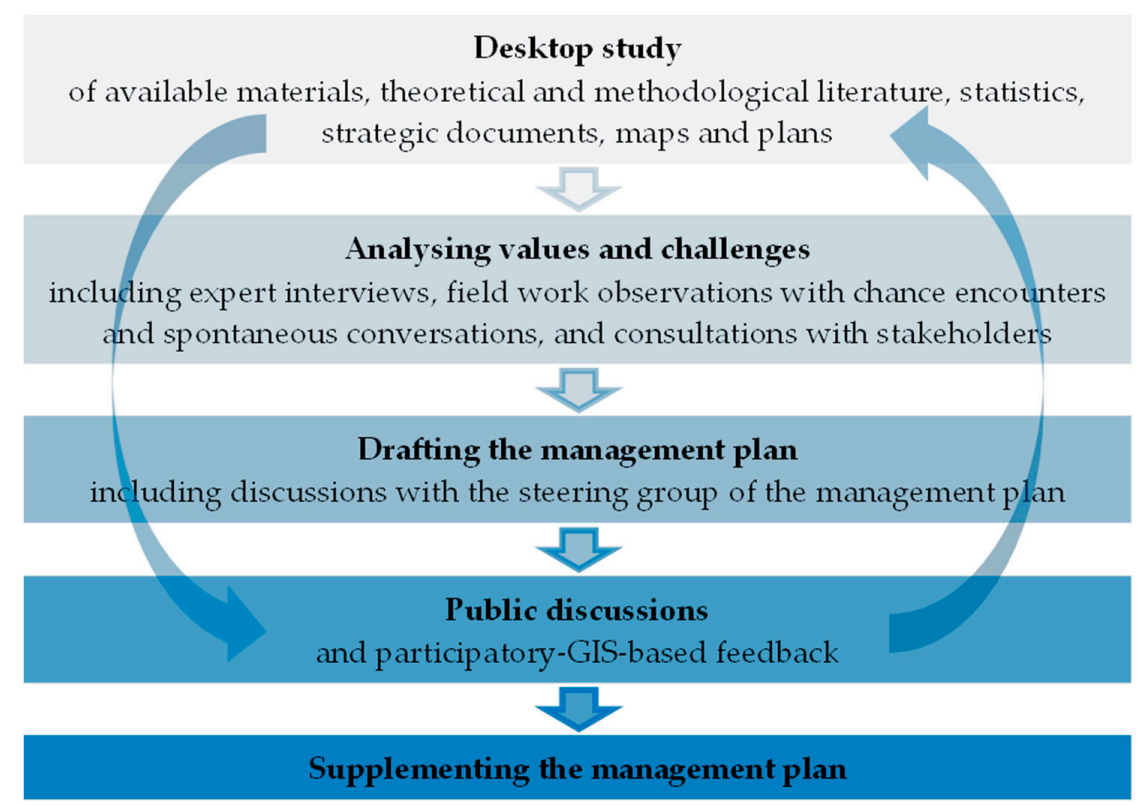

Figure 3. Landscape planning process with iterative loops where initial results feedback into deeper investigations. 
During the course of working on the development of the ICZM we became aware of the importance of the role of culture in the self-organisation of coastal fishers, and also of some of the challenges facing CoPs involved in reinstating fish foodways in terms of sustaining the traditional coastal landscapes. Community cooperation and multifunctionality became the threads interceding all the sub-chapters of Lääne-Viru ICZM [7]: Recreation, mobility, and entrepreneurship to combat seasonality. The SustainBaltic project provided us with the access to the communities and the methodology for engaging with them was developed in this context.

\subsection{Public Participation and Stakeholder Involvement}

This planning-oriented study focused on communication with all level stakeholders. The mixed-method primarily qualitative case study relied on semi-structured and focus group interviews with sea-related people from ministry and state agencies, county and municipality government, and local interest groups. The snowball method was used to find the interviewees: Starting from the formal positions, email lists of local activists, suggestions, and chance encounters during fieldwork. Stakeholders included local community members as participants of public meetings, heads of villages, harbour and museum owners, harbour managers, tourist facilitators, maritime rescue brigades, among others-and the most vocal of them were the coastal fishers' CoP. In the Estonian context, the same person can wear two or more different hats simultaneously; for example, fishers double as harbour master, municipal specialist, retired environmental inspector, and art professor. Therefore, their understanding of the world and experience of life is rather wide and varied and the estimated average age is well above 50. The majority of the fishers were men. All the discussions were fruitful and long as well as constructive producing many new ideas about how to develop local life and politics.

Two focus group interviews with fishers were conducted in September and October 2017, contacted through the Society of Viru Coastal Fishers [52]. The topics included: Embedded skills and situated practices of fishing, social networks co-existing with communities of fishers, dynamics and care bound to fish reserves, accessibility issues related to the shoreline, and the governance of coastal fishery. The participants were also encouraged to allocate particular values, points of accessibility, and fishing grounds on the map, which nobody cares to reveal. The combination of different methods triggered discussion [53], which at some points turned into heated debates.

Interviews were analysed with conventional qualitative content analysis to disclose topics relevant to the local community. These encounters revealed some insights into self-organisation, situated knowledge, landscape values, and social tensions embedded in the CoP among coastal fishers. Much of the rich material collected did not end up in the ICZM plan and made us think about the role of fishers in coastal sustainability.

The main challenge was to systematise this vast material pertaining to all aspects of coastal life even for the ICZM. At the same time, more individual walk-along interviews would have given deeper knowledge about landscapes yet focus group interviews exposed many intriguing themes within community itself. The participatory planning process offered the possibility for local people to meet and also carry on some informal self-organisational activities.

\section{Results}

The collage of empirical materials will be presented within a theoretical and thematic focus on the self-organisation of $\mathrm{CoP}$ among coastal fishers in reinstating foodways for the cultural sustainability of coastal landscapes.

In this study, the main realisation for us was the still-ongoing disrupted nature of the maritime culture even after a quarter of a century of independence. Only a few people living on the coast engage in sea-related activities daily. The (maritime) culture as an underlying condition for sustaining coastal landscapes is a wider challenge. 


\subsection{Self-Organisation through Community of Practice}

Intangible and tangible cultures permeate diverse aspects of coastal fishing life, affecting acquired skills, values, traditional ecological knowledge, know-how, situated practices of fishing, etc. No learning experience happens in a vacuum but through social interactions with culture as a mediator, yet it can accumulate in an individual. Cultural capital as an achievement in development fosters also social capital. Culture affects the ways in which coastal fishers organise their surroundings along social practices, which mobilise different cultural aspects of the sustainability of coastal landscapes.

Self-organisation starts from the person itself. To become a fisher requires a considerable amount of expertise, skill, time, and money. To start from scratch, a lot of things are necessary. For an outsider, the legal framework seems complicated. Even in the case of free of charge recreational fishing, there are fishing rules to adhere to; for example, knowing which gear is allowed, where the public water bodies are, time restrictions, using only natural bait, and so on. A fee for fishing rights with more than one simple hand line but without heavy equipment can be achieved, for instance, via mobile payment ( $1 €$ for 24 hours in 2019) [54].

Professional fishers have to compete with more sophisticated recreational ones to get a fishing card, which also obliges them to report on the catch. Here, it should be taken into account that several recreational fishers living in coastal villages have to compete for fishing licences with other fisher folk from all over Estonia every year. Professionals have to use specified gear and have a fisher's or fishing boat permit. They have to be registered in the business register and the majority of them function as entrepreneurs (most of them are self-employed), which should have a positive effect on self-organisation and entrepreneurship. Professionals have to have a level 4 vocational qualification in coastal fishing. They have to obey restrictions on fish types, locations, times, equipment, and so on. The Ministry of Rural Affairs, which is responsible for professional fishing, lists the eight most important legislative texts in order to monitor coastal fishing [55]. Luckily, there are also several fishing internet portals that try to condense these materials via forums.

To make things even more complicated, there is also a historic catch right for more than 10 fish nets with professional gear for a registered professional and this can be inherited but also sold and bought like stocks in the market. An entrepreneur's share of his/her historical catch right is calculated based on a three-year ratio to the catch opportunities of others, which is calculated for the current year with the county or other water area share rights [55]. Therefore, CoPs among coastal fishers are sub-divided into several multi-layered interest groups.

When the legal framework is all clear, then equipment including boat, nets, and rubber boots or waders need to be acquired (Figure 4). The gear needs care and repair and a place to store them, especially during the winter, and this all helps create a coastal landscape. The fishers in the interviews sometimes complained that on poor days, the fuel they have used costs more than what they receive as income from selling the fish.

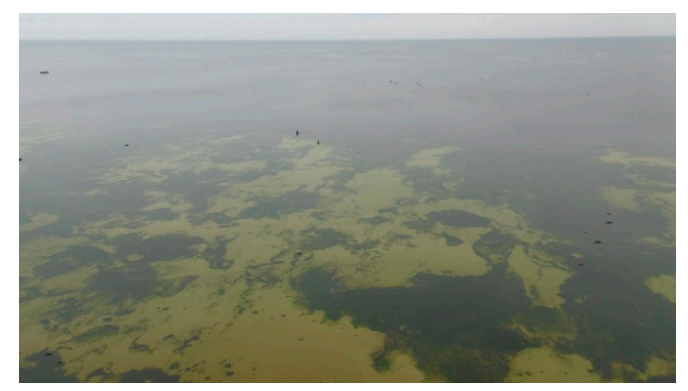

(a)

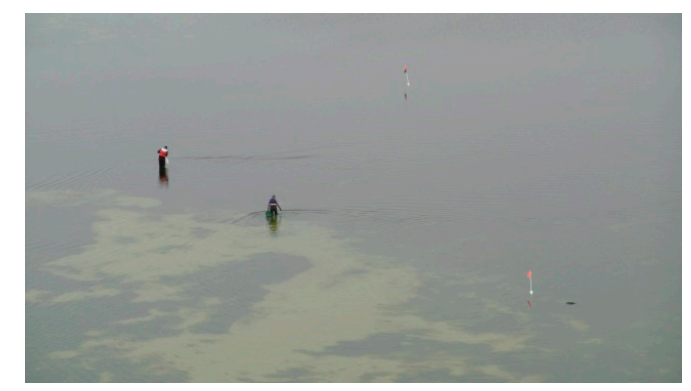

(b)

Figure 4. Sometimes coastal fishing does not require a boat. A view of (a) fishers also showing (b) their fish net flags as seen from Türisalu klint in Harju county, Estonia (photograph: Anu Printsmann, 1 October 2017). 
Sea-faring, even in coastal waters, needs skill, even though the fisher folk do not venture beyond two nautical miles $(3.7 \mathrm{~km})$ from the coastline. Fishers go looking for deeper water away from the coastline during the warmer summer period. The offshore motion range of coastal fishers is usually up to the 20-metre depth line. Less-experienced fisher folk remain within the bays and even there one has to pay attention to the currents, shallows, and choppy conditions. Within a couple of years of practice, more distant islets are also within the reach of those with newly gained skill. Rare trips to Finland (around $60 \mathrm{~km}$ ) are managed with faster and safer boats. GPS devices are often used to navigate, and this is especially necessary in the mist and on open water. However, fishers also still use the tallest chimneys and mobile communication masts along the coast. According to coastal fishers, the fishing zone, which is specified on the fishing licence, is followed at sea based on experience and there have been no problems. Navigational expertise, as learned and experienced in the seascape, contributes to cultural sustainability.

In addition, it is necessary to decide when and where to go (within the legal rights) and this kind of traditional ecological knowledge (cultural sustainability) needs time to be built up. Sometimes this understanding cannot be explained in measurable terms but is more of a gut feeling. In addition to the seasonal and weather component, fish behaviour (periods and routes of migration, preferences for shallower or deeper, warmer or colder, standing or moving water) and how this changes over decades also becomes important [33]. In Käsmu village, there is a man whose forefathers also fished, and he is known to never return empty handed. The other fishers admitted that they sometimes copy his behaviour. Therefore, the act of fishing binds self-organisation, CoPs, foodways, the coastal landscape, and culture as a capital as an achievement in development worthy for maintaining for future generations.

\subsection{Community Matters}

The role of culture in sustaining the coastal landscapes refers to shared activities within a group being simultaneously a mediator and an underlying condition. Culture mediates moral codes, behavioural rules, and what kind of conduct is tolerated by others in business terms or otherwise in a given environment. Coastal fishers' CoP forms a cultural way of life binding them socially and economically, and at the same time connecting them to the surrounding world.

Coastal fishing can be done alone but sharing with colleagues makes it easier to take the fish nets out and divide the expenses. In older times, grandfathers and fathers tended to take their children out on the sea. Nowadays, it is more common to learn the habit from co-workers or friends as nobody is a full-time professional (non-industrial) fisher, starting alone is difficult, and some initiation rites along the way are to be expected for a newcomer.

As fish forms a resource in a common pool, then in addition to legislation and quotas, common understanding, best practices, and codes of conduct apply [56]. Fish nets are fixed on the basis of licences and agreements among the coastal fishers CoP. These agreements can last several generations and failure to comply with them creates conflict. This is not a completely closed system and there are so-called border crossers, who want to get to the best fishing sites early in the morning. Professional fishers, whose maximum engine power has been specified, compete with recreational fishers who often have faster boats. With historic catch rights involved, some sections of the sea might be already "closed" upon arrival. Setting your nets too close to somebody else's is not looked upon with a friendly eye.

Due to natural conditions, the mooring places are plentiful. Several docking sites have been marked in the coastal zone as official unloading places to which the fishers added others during the interviews. These are used to deliver the catch and provide the catch report and, if necessary, any supervision or official monitoring. Sometimes these sites are equipped with some basic infrastructure, often consisting mainly of a practical arrangement of rocks. Fishers do not often want to share their landing place with a stranger; however, there are some shared sites. The maintenance and use of mooring places are based on mutual agreements. Some fishers have the luxury of a docking site on their property; others use state or municipal ones. 
To access a specific landing site by car, the fisher must apply for a permit from the Environmental Board to drive in the coastal zone every year. The permit applies to a particular vehicle and route. One fisher can also use several places, depending on the weather conditions. Driving on private roads is possible thanks to informal agreements. At the same time, the situation may change, so other options should be considered as a long-term solution. As a rule, coastal fishers do not have problems related to mooring sites. It means that their cultural competences are well established to operate between social, ecological, and also economic dimensions of coastal accessibility.

The construction of additional small-craft harbours has improved access to the sea. As several of these have been constructed with the help of EU measures, local fishers have lower usage fees there compared to (foreign) tourists. Due to natural reasons and opposition from local communities, the harbours are small and fill up with yachts quickly. The local community wants to preserve the traditional historical coastal landscape (culture as a capital) without huge constructions that can also have a negative impact on sandy beaches. These negotiations highlight thresholds in connecting nature-based values into commodified seasonal services (e.g., new extended harbours). Another worry is that villages cannot accommodate so many visitors and traffic. Building a harbour is not cheap. Võsu harbour filled with boats within three years but the plan to extend outside the piers is too expensive, and so there is competition for moorings. Building expenses are hard to earn back as earnings do not even cover the operating costs. On the other hand, small-craft harbours as nodes of maritime culture with restaurants and some accommodation have become favourite places to enjoy the sunset or take a photograph of the children in a boat-and this upsets the fishers if permission is not sought first. The knowledge of how to behave has been lost with the interruption of the maritime culture, indicating the fragility of cultural sustainability.

In addition to CoPs among coastal fishers, there are also more formal non-governmental organisations. Many of the common concerns can be addressed there and project applications prepared. The Society of Viru Coastal Fishers gathers together around 70 people. Not all of them are professionals and not all professionals are in the Society. In the summer of 2017, they discussed whether they should acquire an ice-machine in Võsu. Fish need to be chilled fast and the ice-machine could be a communal facility for all of the fishers.

Several problems and suggestions from the coastal fishers deal with the fisheries policy in more general terms, which, in reality, affect maritime culture and the related environment. For example, fishing in Estonia is currently governed by five different state agencies: The Ministry of Rural Affairs, the Ministry of the Environment, the Environmental Board, the Environmental Inspectorate, and the Veterinary and Food Board. In the context of the CoPs among coastal fishers, a better balance needs to be sought with recreational fishers and nature protection (seals, sea otters, cormorants). Similar tensions with nature protection have emerged in the context of the sea around the Finnish Archipelago, where fishers campaign for wider opportunities to hunt seals and many cormorant colonies have been illegally destroyed [11]. The proposal from the fishers is to address coastal fishing as part of the local lifestyle, in the same way as there are exceptions for small-island dwellers.

Coastal fishers are worried about the decline in fish stocks due to environmental pollution (climate change is much less frequent in conversations) and inadequate monitoring of poaching and catching spawning salmon from the mouths of the rivers and bridges, thereby threatening foodways as sea/landscapes. There is not enough fish, and so the age-old profession is near extinction, as youngsters are more interested in jet ski slalom races through the fish net flags rather than working hard in a low-paying job. Fishing allows some spare time so alternative earning opportunities are most welcome, as nobody can collect a full salary from their catch. One of the easiest ways is to take tourists or locals out on the sea but this is a very seasonal occupation. Fishing as cultural capital indicates ways of translating certain know-how of fishing into additional capitals of tourism services, which simultaneously could contribute to the maintenance of coastal landscapes as well. 


\subsection{Food}

The food brings together diverse cultural aspects of coastal landscape sustainability dynamics. Food can serve as cultural capital in its own right: How the fish has been traditionally processed and the dishes made, for example. Food can be seen as a mediator in culture, bringing together the self-organisation practices among coastal fishers creating foodways and safeguarding traditional landscapes. Finally, food is a cultural underlying condition as foodways cater for economic development, sometimes at the expense of environmental wellbeing and causing social inequalities.

The fish are unloaded at official sites. Every fisher can retain $30 \mathrm{~kg}$ of fish for personal use every 24 hours. As one of the fishers explained, the village usually knows when he is out fishing, and on the way back from the peninsula he has usually sold his catch via mobile calls while riding back to the village on his bicycle. Therefore, no sophisticated e-platforms are used, and just a mobile call will do the trick. Foodways as sea/landscapes connect CoPs among coastal fishers to other social ties and groups for distributing the fish.

There is no fisher in the world who would care to say that there is plenty of fish, as this would jinx the catch, but the real statistics are not too good either (Figure 5). Recent years have been especially difficult in Lääne-Viru county, and one of the reasons for this can be the expansion of invasive species, such as the round goby (Neogobius melanostomus) (Figure 6).

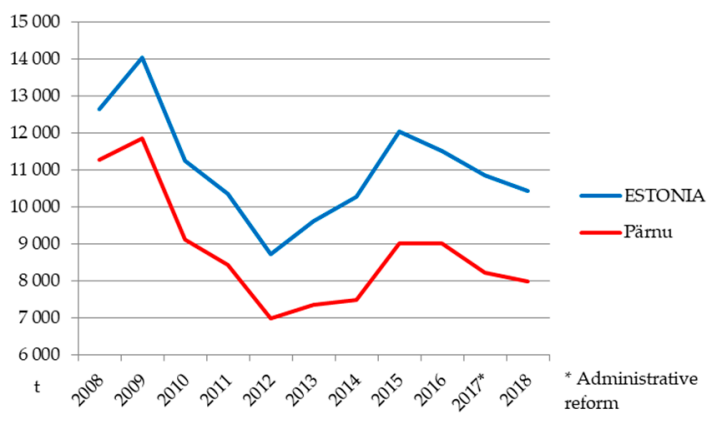

(a)

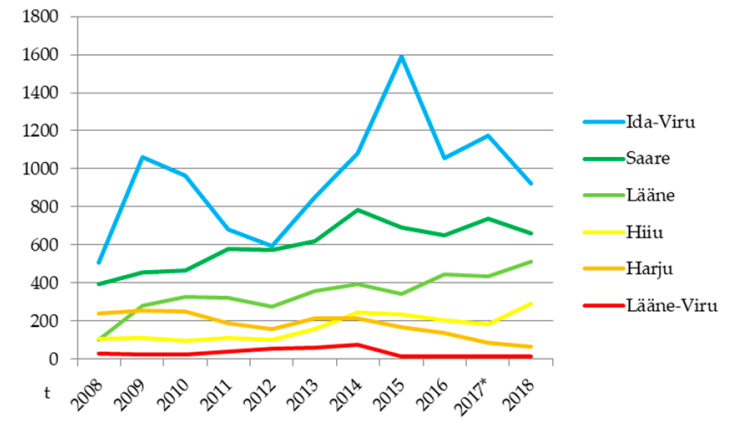

(b)

Figure 5. Fish catch in Estonian counties bordering the sea in tons (a) in whole of Estonia and Pärnu county; (b) the rest of the counties bordering the sea in tons (data: Ministry of Rural Affairs, 31 January 2019/4 February 2019 [57]).

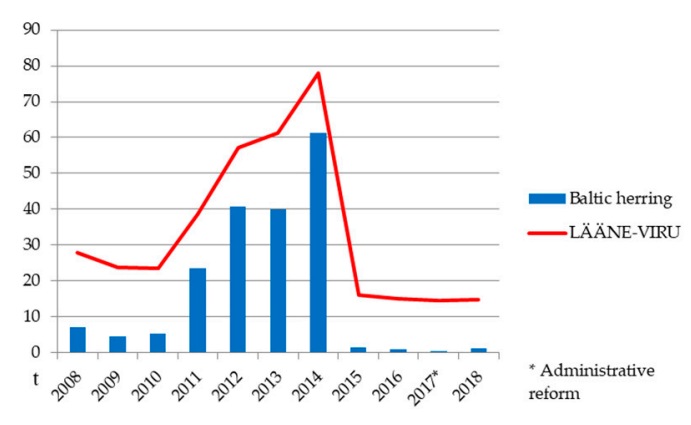

(a)

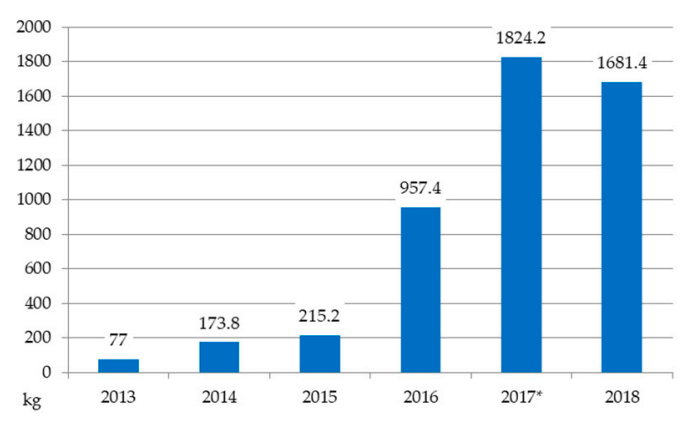

(b)

Figure 6. (a) Baltic herring (Clupea harengus membras) comprises the top catch within the 34 species of fish caught in Lääne-Viru county in tons. (b) The catch of round goby (Neogobius melanostomus)—invasive to the Baltic Sea-in Lääne-Viru county in kilograms (data: Ministry of Rural Affairs, 31 January 2019/4 February 2019 [57]).

In 2018, there were 72 self-employed or limited-liability companies in Lääne-Viru county that had reported a catch above zero [58]. The lowest was $2.9 \mathrm{~kg}$ and the highest was $1298.3 \mathrm{~kg}$ with an average 
of $205.9 \mathrm{~kg}$. There is little cooperation in the CoP among coastal fishers with regards to selling their produce together. One of the reasons is their sporadic activity; second, the catch is too inconsistent to make advance plans; and third, to drive to local towns (Rakvere approximately $40 \mathrm{~km}$ ) or further towns (capital Tallinn $80 \mathrm{~km}$ ) to sell costs extra equipment, time, money, and effort, and the result may not be worthwhile. Therefore, the majority of fishers settle with wholesalers despite the low prices (Table 1).

Table 1. Medium wholesalers' prices of selected fish species for 2018 (data: Ministry of Rural Affairs, 22 January 2019 [59]).

\begin{tabular}{cccc}
\hline Fish & High end EUR/kg & Fish & Low end EUR/kg \\
\hline Eel & 9.43 & Bream & 0.47 \\
Salmon & 7.5 & Prussian carp & 0.27 \\
Sea trout & 7.17 & Redeye/rudd & 0.21 \\
Rainbow trout & 6.88 & Round goby & 0.19 \\
Whitefish & 5.91 & Baltic herring & 0.17 \\
\hline
\end{tabular}

In Lääne-Viru county, 24 fish species were caught in 2018. Of these, 22 had listed with the price of wholesalers [59] making the total wholesale value of the catch shy of 60,000 euros. Dividing this by 70 fishers makes 850 euros as the average income per fisher per annum.

Coastal areas are especially popular during the summer season, and in recent years, the revival of maritime culture has gained some momentum. Interest in fine foods [8] has also reached Estonia. In Võsu, only one diner is open during winter, but in recent summers, there have been around 10 pop-up restaurants. It would be expected that these should concentrate on seasonal and local food, yet no local fish is served. There are several reasons from both sides. The main one is that the fishing season peaks in spring and autumn, whereas vacationers prefer the summer months of June until August. The catch is too unreliable in terms of volume and species to have a fixed menu. In addition to paperwork, there is the eternal negotiation about the price and descaling. Health recommendations have also been brought forward, despite that the general awareness on food safety in Estonia is not as high as in some other countries on the Baltic Sea. The distribution of toxins also depends on sea currents, which in the Finnish Gulf, is anti-clockwise. The European Food Safety Authority has reduced the tolerable weekly intake of dioxins and dioxin-like PCBs (polychlorinated biphenyls) by seven times [60] due to new scientific inquiries, albeit that the toxin levels have been decreasing for the past 30 years. Since 1980s these unwanted by-products of thermal and industrial processes have been banned in EU. The main sources for these harmful substances are fish (in particular fatty fish), cheese, and livestock meat. The Estonian Ministry of Rural Affairs still encourages eating fish with caution [61]:

1. Less fatty fish should be favoured (but popular salmon, Baltic sprat (Sprattus sprattus balticus), and Baltic herring (Clupea harengus membras) are fatty)

2. Prefer younger and smaller $(<22 \mathrm{~cm})$ Baltic herrings or eat them only couple of times per month

3. Avoid eating fatty fish from the Baltic Sea more than three times per week, and no more than two portions at a time-not more than $300 \mathrm{~g}$ of one species in a week

4. Remove the skin of the fish and fillet them.

Fish consumption is still seen as a healthy choice, as omega-3 fatty acids are beneficial for the cardiovascular system. Fish should not be avoided, but in order to distribute health risks, a balanced and diverse diet is important, especially for youngsters, pregnant women, and the elderly [61].

With an uncertain catch, low income, and potential decreases in the consumption of fish, the CoP among coastal fishers will have to find auxiliary activities to sustain the foodways in coastal landscapes or a very important cultural facet will be lost. In the changed circumstances, fishers must think more about increasing the value of fish and doing other work. To find the right ancillary activities, coastal fishing could be linked to skills and areas such as catering, the food industry, fishing equipment, and the recreation economy either through boat tours or renting out accommodation—distributing things, 
knowledge, and resources. Among other things, the European Fisheries Fund supports the acquisition of infrastructure for these areas of activity as well as for the diversification of activities.

\section{Discussion}

The connection between fishing and coastal landscape offers several associated directions for future development. The fish caught by the CoPs among coastal fishers follows intricate, shorter, or longer foodways to end up on our dining tables. In the process of navigating the sea, traditional ecological knowledge [33] has been accumulated over many years broadening the concept of landscape to include sea areas. Fishers have gained a mental map of coastal waters that is under constant change due to the weather, seasons, pollution, and climate. This affects the amount of fish caught, consumption habits, and price, which are all currently threatening the future of the profession of a coastal fisher.

The current state of the self-organisation of the non-industrial professional coastal fishers could be better. Tensions do not seem to be a major problem, but rather the interplay between traditional lifestyles and bureaucracy, for example the eased requirements for small-island dwellers. Fishers have managed to go to the sea, share common resources at sea and on land, agree on landing sites, distribute the catch through social ties and wholesalers, but they could benefit from much more cooperation and co-produced foodways, finding auxiliary activities to support their livelihood, their way of life, and local life. Considering that coastal fishing has not been continuous, perhaps there are better days ahead, especially with some EU support before these CoPs are disregarded altogether. Small-scale industries should also be acceptable by general public. As in the Finnish Archipelago, the revitalisation of fishing livelihoods seems realistic because of the value placed on local fish products and fishing traditions, and new synergies for revitalisation can be gained through networks between coastal fishing, recreation, and nature protection [11]. The stakeholders in the case study proposed concrete ways that small-scale fishing could be sustained in coastal landscapes; for example: The engagement of fishers' know-how and infrastructure in tourism and vocational education (e.g., boat trips, traditional workshops); involving the skills of coastal residents in seasonal paid environmental care work (e.g., renovating hiking trails); advancing shared spaces for valuing the catch (e.g., equipment in small harbours). The maintenance of public access to the shore and balanced management of fish stock and of fishing rights are also seen as important factors co-producing coastal landscapes and small-scale fishing [7].

The connected cultural practices of how fish are brought from the sea to the table are called foodways. In the process of developing foodways, land-sea interactions gain a specific character that is valued by many domestic as well as foreign tourists. This coastal landscape consists of sightings of boats at sea or on the shoreline, seeing fish nets drying by net sheds, identifying fish smoking devices and smelling the air, sitting in a marina, rustic or summer house where much of the decor is sea-inspired, and travelling the coastal road network interacting with the sea. From the perspective of the sustainability of coastal fishing, it is important to keep representing the interests of coastal fishers in the process of managing small-craft harbours in the region. For example, the Society of Viru Coastal Fishers has concluded such a contract with the Võsu harbour for 25 years. For private ports, this is not as regulated. Therefore, the active participation of coastal fishers should be encouraged in the long-term reconstruction and management of small-craft harbours. The coastal landscape could be even more connected when local fish could be served during summer in modern pop-up restaurants created to serve local and seasonal food, which in turn, could contribute to the CoPs among coastal fishers. There are several ways to solve the problem: Fishers and restaurants could come up with bilateral agreements instead of the wholesalers, fishers could service the restaurants as a group, the restaurants could prepare standard menus on "catch of the day" meals with seasonal vegetables, and previously salted or smoked fish could also be on the order as traditional food. Potential exists to rework the social and spatial connections embedded within food resources, and to use the cultural aspects of these connections to modify sustainability perspectives. The shifts and simultaneous involvements, from (individualised) culture as capital towards shared culture as mediator and context, can re-socialise 
foodways within communities and landscape maintenance laying the groundwork for culture as an underlying condition for local life.

Traditional ecological knowledge in connection with community self-organisation creates foodways that produce a landscape that means sharing experiences across time. Culture as the fourth pillar sees intrinsic value in heritage, maintaining, upholding, and sustaining what has been considered worthwhile [17]. For example, something very mundane like net sheds have been preserved because there were no funds to modernise them and now, they serve as one of the symbols of the area. Nowadays, even some summer cottages copy their style [62]. Something that may not have use-value may disappear or gain new functionality. Just sustaining things, making them work longer, caring for them, and repairing them does contribute to sustainability in its broadest sense. The importance of cultural capital is historically embedded in the region. Being a renowned summer resort area in the past, various artists have portrayed their emotions and impressions in artworks, which act as a cultural reference. As such, when people visit the area they want to "see" the atmosphere depicted in those artworks. The coastline of Lääne-Viru county in its rather underdeveloped state compared to many other European countries can use culture in creating a summer peak season that saves the local community from complete marginalisation during the low season and, thus, preserving the cultural landscape.

Culture having a mediating role in achieving ecological, economic, and social sustainability [17] treats the time horizon differently. It cannot be expected that coastal landscapes will be frozen in time as traditional landscapes [63]; culture mediates and adapts suitable practices. Rowing boats have been replaced by motorboats, and instead of everybody owning a boat, a jet ski can now be rented to feel a connection with the sea. Such a basic activity as fishing for food has not changed in essence but the practices involved in doing it have. There are improvements in the equipment and refrigeration, transport and marketing among others. Our results suggest that culture affects ecological sustainability. For example, environmental awareness has also been increased through the legal regulations of aspects such as waste management or cleansing agricultural discharge. Cultural landscapes can be turned into profit-providers, as described above. When a local community agrees to value the local way of life, taking care of their surrounding environment becomes essential $[64,65]$. The better quality of life attracts citizens and enhances social sustainability.

The current study indicates the wider dynamics of coastal areas mobilising communities in fish foodways and environmental change [11,42]. Lääne-Viru county added a particular context to these dynamics, which affects the revival of coastal fisheries and related landscapes in Estonia and beyond. In other regions of Estonia, the decrease of fish catch has been smaller and catch volumes remain remarkably higher compared to Lääne-Viru. The reconstruction of small harbours along the whole shoreline of Estonia and increasing awareness about locally produced foodways can positively contribute to the continuation of coastal fishery practice. There is a challenge to bring cultural aspects explicitly into sustainability frameworks for formulating the (public) values of fish foodways in coastal landscape planning initiatives.

Carefully adapting to modern ways of life will also change the foodways and the cultural coastal landscape and continue to do so as long as there are fish. Culture can be seen as the key to cautious development, to help people decide whether changes should be accepted [66,67] and how to sustain life in the ecological, economic, and social sphere. The outsiders' attachment to fishing as a positive identity supports the continuance of traditions and coastal landscapes, but on the other hand, this strong identity highlights aspects of "dependency" on fishing, which explains why fishing entrepreneurs feel that alternative forms of employment are difficult to access [30]. This means that the role of culture in sustaining coastal landscapes could be seen as a mediator and context to achieving an integrated sustainability [17] considering both human and more-than-human agents. 


\section{Conclusions}

Self-organisation in CoP among coastal fishers contributes to the cultural sustainability of foodways as sea/landscapes. The bottom-up initiatives or place-based collectives focusing on sustainable food systems are nothing new. Food production has always been a significant shaper of the landscape, albeit in altered forms. Coastal landscapes with their land-sea interactions remind us of the nature of landscapes, where the incorporation of everyday practices, traditional ecological knowledge, and the application of mental faculties do not have to form visible patterns to be considered a habituated space. Shared experiences have accumulated over time, despite the tensions between shared resources, hardships, and multi-level bureaucracy.

The current study illustrates the way particular communities of practice co-exist with coastal landscapes. The fish foodways here provided a fruitful link for analysing dynamic co-existences. The self-organisation of coastal fishers mobilises and distributes certain skills and keeps a lifestyle alive. However, communities of practice also indicate a need for wider social networks and capacities; for example, to sustain fishery reserves and to generate seasonal ancillary activities. Therefore, there is a need to reconsider coastal fish foodways in the cultural sustainability of landscapes, which additional to ongoing practice, can reveal potentials about re-spatialising and re-socialising connections around food.

Culture as a fourth pillar of sustainability can adopt a care-taking culture, meaning that we re-use and mend things as much as possible. On the other hand, it may turn out that celebrating heritage could hinder economic development. Culture as a mediator supports ecological, economic, and social sustainability, meaning constant, steady, and cautious adaptation to change. As change is the most persistent constituent of life, some space should be left for the possibilities that are not yet known to us. While there are fish and health norms that do not advise against the consumption of it, foodways as sea/landscapes in culture as an underlying condition have and will persist through diverse political-economic regimes.

Author Contributions: Conceptualisation, A.P. and T.P.; data curation, A.P. and T.P.; investigation, A.P. and T.P.; methodology, A.P. and T.P.; project administration, A.P. and T.P.; supervision, T.P.; visualization, A.P.; writing—original draft, A.P. and T.P.; writing—review and editing, A.P. and T.P.

Funding: This work was supported by the European Union through the European Regional Development Fund Interreg Central Baltic Programme project 354 SustainBaltic (Integrated Coastal Zone Management (ICZM) Plans for Sustaining Coastal and Marine Human-ecological Networks in the Baltic Region) 1.09.2016 until 30.11.2018; Interreg Baltic Sea Region Programme project \#R098 Land-Sea-Act (Land-sea Interactions Advancing Blue Growth in Baltic Sea Coastal Areas) 1.01.2019 until 30.06.2021; Estonian Research Council (ERC) Institutional Research Funding grant IUT 3-2 Culturescapes in Transformation: Towards an Integrated Theory of Meaning Making, 01.01.2013 until 31.12.2018; ERC Personal Research Funding (PUT) team grant PRG 398 Landscape Approach to Rurbanity, 1.01.2019 until 31.12.2023.

Acknowledgments: We are grateful to our interviewees for their willingness to cooperate and project colleagues for support in discussing the ideas.

Conflicts of Interest: The authors declare no conflicts of interest.

\section{References}

1. Appadurai, A. The Social Life of Things: Commodities in Cultural Perspective; Cambridge University Press: Cambridge, UK, 1986.

2. Roe, M. Food and Landscape. Special issue. Landsc. Res. 2016, 41, 709-713. [CrossRef]

3. Zeunert, J.; Waterman, T. Routledge Handbook of Landscape and Food; Routledge Handbooks; Routledge, Taylor \& Francis Group: London, UK, 2018.

4. Dubois, A. Nurturing proximities in an emerging food landscape. J. Rural Stud. 2018, 57, 1-12. [CrossRef]

5. Marsden, T.; Banks, J.; Bristow, G. Food supply chain approaches: Exploring their role in rural development. Sociol. Rural. 2000, 40, 424-438. [CrossRef]

6. University of Turku. SustainBaltic. Available online: https://www.utu.fi/en/sites/SustainBaltic/Pages/home. aspx (accessed on 17 February 2019). 
7. Kuusik, M.; Pikner, T.; Printsmann, A.; Raet, J. Lääne-Viru Integrated Coastal Zone Management Plan. In SustainBaltic: ICZM Plans for Sustaining Coastal and Marine Human-Ecological Networks in the Baltic Region; Tallinn University and Estonian University of Life Sciences: Tallinn, Estonia, 2018.

8. Baldacchino, G. Feeding the rural tourism strategy? Food and notions of place and identity. Scand. J. Hosp. Tour. 2015, 15, 223-238. [CrossRef]

9. Heidkamp, C.P.; Morrissey, J. Towards Coastal Resilience and Sustainability; Routledge, Taylor \& Francis Group: London, UK, 2018.

10. Sauer, C.O. The morphology of landscape. Univ. Calif. Publ. Geogr. 1925, 2, 19-53.

11. Salmi, P. Constraints and opportunities for small-scale fishing livelihoods in a post-productivist coastal setting. Sociol. Rural. 2015, 55, 258-274. [CrossRef]

12. Soini, K.; Birkeland, I. Exploring the scientific discourse on cultural sustainability. Geoforum 2014, 51, $213-223$. [CrossRef]

13. Dessein, J.; Soini, K.; Fairclough, G.; Horlings, L. Culture in, for and as Sustainable Development. In Conclusions from the COST Action IS1007 Investigating Cultural Sustainability; University of Jyväskylä: Jyväskylä, Finland, 2015; Available online: http://www.culturalsustainability.eu/conclusions.pdf (accessed on 17 February 2019).

14. Routledge Studies in Culture and Sustainable Development. Available online: https://www. routledge.com/Routledge-Studies-in-Culture-and-Sustainable-Development/book-series/RSCSD (accessed on 17 February 2019).

15. Hawkes, J. The Fourth Pillar of Sustainability: Culture's Essential Role in Public Planning; Cultural Development Network; Common Ground: Melbourne, Australia, 2004.

16. Birkeland, I. Cultural sustainability: Industrialism, placelessness and the re-animation of place. Eth. Place Environ. 2008, 11, 283-297. [CrossRef]

17. Soini, K.; Dessein, J. Culture-sustainability relation: Towards a conceptual framework. Sustainability 2016, 8, 167. [CrossRef]

18. Anderson, J. A Solid Sufficiency: An Ethnography of Yeoman Foodways in Stuart England. Ph.D. Thesis, Folklore and Folklife Department, University of Pennsylvania, Philadelphia, PA, USA, 1971.

19. Mels, T. Nature, home, and scenery: The official spatialities of Swedish national parks. Environ. Plan. D Soc. Space 2002, 20, 135-154. [CrossRef]

20. Olwig, K.R. Recovering the substantive nature of landscape. Ann. Assoc. Am. Geogr. 1996, 86, 630-653. [CrossRef]

21. Olwig, K. Landscape, Nature, and the Body Politic: From Britain's Renaissance to America's New World; University of Wisconsin Press: Madison, WI, USA, 2002.

22. Mitchell, D. Landscape. In Cultural Geography. A Critical Dictionary of Key Concepts; Atkinson, D., Jackson, P., Sibley, D., Washbourne, N., Eds.; I.B. Tauris: London, UK, 2005; pp. 49-56.

23. Sooväli-Sepping, H.; Printsmann, A.; Palang, H. Sustaining Russian Old Believers landscapes of fish and onions in Estonia. In The Routledge Handbook of Landscape and Food; Routledge handbooks; Zeunert, J., Waterman, T., Eds.; Routledge, Taylor \& Francis Group: London, UK, 2018; pp. 92-100.

24. Widgren, M. Can landscapes be read? In European Rural Landscapes: Persistence and Change in a Globalising Environment; Palang, H., Sooväli, H., Antrop, M., Setten, G., Eds.; Kluwer: Dordrecht, The Netherlands, 2004; pp. 455-465.

25. Peters, K.A.; Steinberg, P.E.; Stratford, E. Geopolitical Bodies, Material Worlds. In Territory beyond Terra; Rowman \& Littlefield International: London, UK, 2018.

26. Wylie, J. Landscape. In Key Ideas in Geography; Routledge: London, UK, 2007.

27. Wylie, J. Landscape, absence and the geographies of love. Trans. Inst. Br. Geogr. 2009, 34, 275-289. [CrossRef]

28. Lave, J.; Wenger, E. Situated Learning: Legitimate Peripheral Participation; Cambridge University Press: Cambridge, UK, 1991.

29. Kaufmann, M. Emergent self-organisation in emergencies: Resilience rationales in interconnected societies. Resilience 2013, 1, 53-68. [CrossRef]

30. Ross, N. Understanding the fishing 'community': The role of communities of the mind. Sociol. Rural. 2015, 55, 309-324. [CrossRef]

31. Amin, A.; Roberts, J. Community, Economic Creativity, and Organization; Oxford University Press: Oxford, UK, 2008. 
32. Lave, J. Epilogue: Situated learning and changing practice. In Community, Economic Creativity, and Organisation; Amin, A., Roberts, J., Eds.; Oxford University Press: Oxford, UK, 2008; pp. 283-296.

33. Mustonen, T. Oral histories as a baseline of landscape restoration-Co-Management and watershed knowledge in Jukajoki River. Fenn. Int. J. Geogr. 2013, 191, 76-91. [CrossRef]

34. Sooväli-Sepping, H.; Reinert, H.; Miles-Watson, J. Ruptured Landscapes: Landscape, Identity and Social Change; Landscape series 19; Springer: Dordrecht, The Netherlands, 2015.

35. Antso, K.; Palginõmm, V.; Szava-Kovats, R.; Kont, A. Dynamics of coastal land use over the last century in Estonia. J. Coast. Res. 2011, 11, 1769-1773.

36. Palginõmm, V.; Ratas, U.; Kont, A. Increasing human impact on coastal areas of Estonia in recent decades. J. Coast. Res. 2007, 50, 114-119.

37. Palang, H.; Sooväli-Sepping, H. Are there counter-landscapes? On milk trestles and invisible power lines. Landsc. Res. 2012, 37, 467-482. [CrossRef]

38. Bec, A.; Moyle, B.; Moyle, C. Resilient and sustainable communities. Sustainability 2018, 10, 4810. [CrossRef]

39. SweBoat-Båtbranschens Riksförbund/Swedish Marine Industries Federation. Boating in Brief-in Sweden. Available online: http://service.batbranschensriksforbund.se/file.aspx?afile=97faed62-2d03-480db15f-4830a5810b96 (accessed on 4 November 2018).

40. Eesti statistika. Rahvaarv aasta alguses. Available online: https://www.stat.ee/stat-rahvaarv-aasta-alguses (accessed on 31 October 2018).

41. Maanteeamet. Sõidukite statistika. Available online: https://www.mnt.ee/et/ametist/statistika/soidukitestatistika (accessed on 31 October 2018).

42. Nakhshina, M. 'Without fish, there would be nothing here': Attitudes to salmon and identification with place in a Russian coastal village. J. Rural Stud. 2012, 28, 130-138. [CrossRef]

43. Mozumder, M.; Wahab, M.; Sarkki, S.; Schneider, P.; Islam, M. Enhancing social resilience of the coastal fishing communities: A case study of hilsa (Tenualosa Ilisha H.) fishery in Bangladesh. Sustainability 2018, 10, 3501. [CrossRef]

44. European Commission. Blue Growth. Available online: https://ec.europa.eu/maritimeaffairs/policy/blue_ growth_en (accessed on 10 July 2019).

45. European Commission. Lessons from the European Commission's Demonstration Programme on Integrated Coastal Zone Management (ICZM); European Commission: Luxembourg City, Luxembourg, 1999.

46. European Commission. Communication from the Commission to the Council and the European Parliament on Integrated Coastal Zone Management: A Strategy for Europe; COM/2000/547 final; European Commission: Brussels, Belgium, 2000.

47. European Commission. Council Recommendation of the European Parliament and of the Council of 30 May, Concerning the Implementation of Integrated Coastal Zone Management in Europe; 2002/413/EC L 148/24; European Commission: Brussels, Belgium, 2002.

48. European Commission. Communication from the Commission e Report to the European Parliament and the Council: An Evaluation of Integrated Coastal Zone Management (ICZM) in Europe; COM/2007/0308 final; European Commission: Brussels, Belgium, 2007.

49. Ballinger, R.; Pickaver, A.; Lymbery, G.; Ferreria, M. An evaluation of the implementation of the European ICZM principles. Ocean Coast. Manag. 2010, 53, 738-749. [CrossRef]

50. Tress, B.; Tress, G.; Fry, G.; Opdam, P. From Landscape Research to Landscape Planning: Aspects of Integration, Education and Application; Wageningen University \& Research Frontis Series 12; Springer: Dordrecht, The Netherlands, 2006.

51. Antrop, M.; Van Eetvelde, V. Landscape Perspectives-The Holistic Nature of Landscape; Landscape Series 23; Springer: Dordrecht, The Netherlands, 2017.

52. Virumaa Rannakalurite Ühing MTÜ. Available online: http://www.vrky.ee (accessed on 18 February 2019).

53. Gullino, P.; Devecchi, M.; Larcher, F. How can different stakeholders contribute to rural landscape planning policy? The case study of Pralormo municipality (Italy). J. Rural Stud. 2018, 57, 99-109. [CrossRef]

54. Kalastusinfo. Fishing in Estonia. Available online: http://www.kalastusinfo.ee/sisu/fishing-in-estonia/ fishing-in-estonia.php (accessed on 18 February 2019).

55. Maaeluministeerium. Kutseline kalapüük. Available online: https://www.agri.ee/et/eesmargid-tegevused/ kalamajandus-ja-kutseline-kalapuuk/kutseline-kalapuuk (accessed on 18 February 2019).

56. Dietz, T.; Ostrom, E.; Stern, P.C. The struggle to govern the commons. Science 2003, 302, 1907-1912. [CrossRef] 
57. Maaeluministeerium. Püügiandmed. Available online: https://www.agri.ee/et/eesmargid-tegevused/ kalamajandus-ja-kutseline-kalapuuk/puugiandmed (accessed on 18 February 2019).

58. Maaeluministeerium. Püügiandmed; 31.12.2018/22.01.2019. Available online: https://www.agri.ee/et/ eesmargid-tegevused/kalamajandus-ja-kutseline-kalapuuk/puugiandmed (accessed on 4 March 2019).

59. Maaeluministeerium. 2018. a keskmised kala esmakokkuostuhinnad. Available online: https://www.agri.ee/ sites/default/files/content/ministeerium/aktid/kaskkiri-2019-10-esmakokkuostuhinnad-2018.pdf (accessed on 3 March 2019).

60. European Food Safety Authority. Dioxins and related PCBs: Tolerable Intake Level Updated; 20.11.2018. Available online: http://www.efsa.europa.eu/en/press/news/181120 (accessed on 6 March 2019).

61. Maaeluministeerium. EFSA avaldas uue dioksiinide riskihinnangu; 20.11.2018. Available online: https://www.agri.ee/et/uudised/efsa-avaldas-uue-dioksiinide-riskihinnangu (accessed on 6 March 2019).

62. Printsmann, A.; Kõivupuu, M.; Palang, H. The dual character of landscape in the Lahemaa National Park, Estonia. In Landscapes, Identities and Development; Roca, Z., Claval, P., Agnew, J., Eds.; Ashgate Publishing: Farnham, UK, 2011; pp. 51-66.

63. Antrop, M. Sustainable landscapes: Contradiction, fiction or utopia? Landsc. Urban Plan. 2006, 75, $187-197$. [CrossRef]

64. Nassauer, J.I. Care and stewardship: From home to planet. Landsc. Urban Plan. 2011, 100, 321-323. [CrossRef]

65. Bieling, C.; Plieninger, T. The Sciece and Practice of Landscape Stewardship; Cambridge University Press: Cambridge, UK, 2017.

66. Viik, T.; Kaljundi, L.; Printsmann, A.; Palang, H. Sustainability through alteration: Eastern Baltic manors in the Estonian tradition. In Theory and Practice in Heritage and Sustainability: Between Past and Future; Routledge Studies in Culture and Sustainable Development; Auclair, E., Fairclough, G., Eds.; Routledge: London, UK, 2015; pp. 147-160.

67. Palang, H.; Soini, K.; Printsmann, A.; Birkeland, I. Landscape and cultural sustainability. Nor. Geogr. Tidsskr. Nor. J. Geogr. 2017, 71, 127-131. [CrossRef]

(C) 2019 by the authors. Licensee MDPI, Basel, Switzerland. This article is an open access article distributed under the terms and conditions of the Creative Commons Attribution (CC BY) license (http://creativecommons.org/licenses/by/4.0/). 